\title{
EVALUASI PERENCANAAN ATAS PAJAK PENGHASILAN (PPH) PASAL 21 SEBAGAI UPAYA MEMINIMALKAN BIAYA PAJAK PADA PT GRAHA POWER ENERGY
}

\author{
Budi Tri Rahardjo *) \\ ${ }^{*}$ Dosen Fakultas Ekonomi Universitas Krisnadwipayana Jakarta \\ Alamat: Kampus UNKRIS, Jatiwaringin Jakarta Timur \\ Email: buditrirahardjo@yahoo.com
}

\begin{abstract}
The purpose of this study is to know the tax planning undertaken by the company is appropriate and in accordance with the applicable tax laws in an effort to minimize the taxation terutangnya. The research method used is descriptive analysis method. The object of research used is evaluation of planning on Income Tax (PPh) Article 21. This research evaluate planning of Income Tax (PPh) Article 21 as an effort to minimize tax cost. The results achieved are having a considerable impact on the company's activities. The owner of the company would want to enjoy the results of his business to the fullest. Therefore it is necessary to prepare a tax planning coordinated with long-term plans and short-term plans of the company. The conclusion is that the difference that occurs after applying the tax planning is a tax savings that can be obtained by the company. Where before the implementation of tax planning, income tax to be paid company is Rp. 425,671,743.25 and seteah doing tax planning to Rp. 341,456,597.75. So obtained tax savings of Rp. $84,215,145.50$ the difference can be used by the company for something more useful and useful.
\end{abstract}

Kata Kunci: Perencanaan Pajak Penghasilan, Efisiensi Biaya Pajak

\section{PENDAHULUAN}

Pembangunan nasional dalam upaya meningkatkan kesejahteraan rakyat baik materil maupun spiritual terus berlangsung secara berkesinambungan dan terus menerus. Dalam upaya untuk mewujudkannya dibutuhkan modal yang tidak sedikit. Dengan tidak mengesampingkan sumber dana dari luar negeri, salah satu wujud kemandirian suatu bangsa atau negara dalam pembinaan pembangunan adalah menggali sumber dana yang berasal dari dalam negeri secara optimal. Sumber dana dari dalam negeri yang paling besar adalah pajak. Pajak adalah iuran kepada negara yang dapat dipaksakan berdasarkan undang-undang dengan tidak mendapatkan kontraprestasi yang dapat ditunjuk secara langsung guna membiayai pengeluaran umum pemerintah dan penyelenggaraan negara.

Pajak juga dapat diartikan sebagai pemindahan sumber daya dari sektor privat (perusahaan) ke sektor publik. Pemindahan sumber daya tersebut mempengaruhi daya beli (purchasing power) atau kemampuan belanja (spending power) dari sektor privat. Agar tidak terjadi gangguan yang serius terhadap jalannya perusahaan maka pemenuhan kewajiban perpajakan harus dikelola dengan baik.

Bagi negara, pajak adalah sumber penerimaan, sedangkan di lain pihak bagi perusahaan, pajak merupakan salah satu kewajiban yang harus dikeluarkan oleh perusahaan sehingga perlu pengelolaan yang baik dan benar untuk menghindari kerugian yang timbul di kemudian hari. Beban pajak yang dipikul subjek pajak khususnya subjek pajak badan, memerlukan perencanaan yang baik, oleh karena itu strategi perpajakan menjadi mutlak untuk mencapai laba perusahaan yang optimal, strategi dan perencanaan yang baik dan benar tentu saja harus legal, sehingga mampu mendorong perusahaan untuk dapat bersaing dengan perusahaan lain.

Pajak Penghasilan adalah suatu jenis pungutan sebagai salah satu sumber pendapatan negara yang ditetapkan 
berdasarkan undang - undang. Perencanaan pajak merupakan salah satu kegiatan dalam manajemen pajak. Manajemen pajak adalah sarana untuk memenuhi kewajiban perpajakan dengan benar tetapi jumlah pajak yang dibayar dapat ditekan serendah mungkin untuk memperoleh laba dan likuiditas yang diharapkan.

Sebagai perusahaan yang berorientasi laba, sudah tentu perusahaan berusaha meminimalkan beban pajak dengan memanfaatkan kelemahan sistem ketentuan pajak yang ada. Skema penghindaran pajak dapat dibedakan menjadi penghindaran pajak yang diperkenankan (acceptable tax avoidance) dan penghindaran pajak yang tidak diperkenankan (unacceptable tax avoidance). Istilah lain yang sering dipergunakan untuk menyatakan penghindaran pajak yang tidak diperkenankan adalah aggresive tax planning dan istilah untuk penghindaran pajak yang tidak diperkenankan adalah defensive tax planning.

Wajib pajak selalu berusaha menekan pajak sekecil mungkin dan menunda pembayaran pajak selambat mungkin sebatas masih diperkenankan peraturan perpajakan. Menekan pajak dapat dilakukan dengan menekan penghasilan atau memperbesar biayabiaya yang boleh dikurangkan dari penghasilan sehingga penghasilan kena pajak menurun atau memanfaatkan peraturan perpajakan yang ada.

Dari sudut pandang Wajib Pajak, tentu berpendapat bahwa sepanjang skema penghindaran pajak yang mereka lakukan tidak dilarang dalam peraturan perundang-undangan perpajakan maka hal tersebut dianggap sah-sah saja (legal). Hal ini dimaksudkan untuk memberi kepastian hukum bagi wajib pajak. Akan tetapi disisi lain, pemerintah tentu juga berkepentingan bahwa jangan sampai suatu ketentuan perpajakan disalahgunakan oleh Wajib Pajak untuk semata-mata tujuan penghindaran pajak yang dapat merugikan penerimaan negara. Dengan perencanaan pajak, diharapkan perusahaan dapat merencanakan pengefisiensian biaya agar dapat meminimalisasikan pajak yang terutang.

\section{LANDASAN TEORI}

\section{Pajak}

Menurut Adriani yang dikutip dari buku Thomas Sumarsan (2013), "Pajak adalah iuran masyarakat pada negara (yang sifatnya dapat dipaksakan) yang terutang oleh yang wajib membayarnya menurut peraturan-peraturan umum (undang-undang) dengan tidak mendapat prestasi kembali yang dapat ditunjuk dan yang digunakan untuk membiayai pengeluaran-pengeluaran umum berhubung tugas-tugas negara untuk menyelenggarakan pemerintahan."

Menurut Dr. Soeparman Soemohamijaya yang dikutip dari buku Waluyo (2013), "Pajak adalah iuran wajib berupa uang atau barang yang dipungut oleh penguasa berdasarkan norma-norma hukum, guna menutup biaya produksi barang-barang dan jasajasa kolektif dalam mencapai kesejahteraan umum."

Konsep Dasar Perpajakan Diana Sari (2013), "Pajak dari perspektif ekonomi dipahami sebagai beralihnya sumber daya dari sektor privat kepada sektor publik. Pemahaman ini memberikan gambaran bahwa adanya pajak menyebabkan dua situasi menjadi berubah. Sementara pemahaman pajak dari perspektif hukum menurut Soemitro merupakan suatu perikatan yang timbul karena adanya undang-undang yang menyebabkan timbulnya kewajiban warga negara untuk menyetorkan sejumlah penghasilan tertentu kepada negara, negara mempunyai kekuatan untuk memaksa dan uang pajak tersebut 
harus dipergunakan untuk penyelenggaraan pemerintah".

Menurut Sommerfeld, Anderson, dan Brock dalam Thomas Sumarsan (2013), " Pajak adalah suatu pengalihan sumber dari sektor swasta ke sektor pemerintah bukan akibat pelanggaran hukum, namun wajib dilaksanakan, berdasarkan ketentuan yang telah ditetapkan lebih dahulu, tanpa mendapat imbalan yang langsung dan proporsional agar pemerintah dapat melaksanakan tugas-tugasnya untuk menjalankan pemerintahan."

Menurut Djajadiningrat yang dikutip dari buku Siti Resmi (2013), "Pajak adalah suatu kewajiban untuk menyerahkan sebagian kekayaan negara karena suatu keadaan, kejadian, dan perbuatan yang memberikan kedudukan tertentu. Pungutan tersebut bukan sebagai hukuman, tetapi menurut peraturanperaturan yang itetapkan pemerintah serta dapat dipaksakan. Untuk itu, tidak ada jasa balik dari negara secara langsung, misalnya untuk memelihara kesejahteraan umum".

Dari pendapat para ahli diatas, menarik kesimpulan bahwa pajak adalah iuran wajib berupa uang atau barang yang dibayarkan rakyat dan yang berhak memungut pajak dari rakyat adalah negara, pajak dipungut berdasarkan undang-undang tanpa timbal jasa dari negara secara langsung dapat ditunjukkan dan digunakan untuk membiayai rumah tangga negara, yakni pengeluaran yang bermanfaat bagi masyarakat.

Fungsi pajak menurut Resmi (2013), yaitu: 1) Fungsi Sumber Keuangan Negara (Budgetair); Pajak mempunyai fungsi budgetair, artinya pajak merupakan salah satu sumber penerimaan pemerintah untuk membiayai pengeluaran baik rutin maupun pembangunan. Sebagai sumber keuangan negara, pemerintah berupaya memasukkan uang sebanyak-banyaknya untuk kas negara. Upaya tersebut ditempuh dengan cara eksistensifikasi maupun intensifikasi pemungutan pajak melalui penyempurnaan peraturan berbagai jenis pajak seperti Pajak Penghasilan ( $\mathrm{PPh})$, Pajak pertambahan Nilai (PPN) dan Pajak Penjualan atas Barang Mewah (PPn BM), Pajak Bumi dan Bangunan (PBB), dan lain-lain. 2) Fungsi mengatur (Regulerend); Pajak mempunyai fungsi pengatur, artinya pajak sebagai alat untuk mengatur atau melaksanakan kebijakan pemerintah dalam bidang sosial dan ekonomi, serta mencapai tujuan-tujuan tertentu diluar bidang keuangan.

Menurut Resmi (2014) terdapat beberapa jenis pajak yang dapat dikelompokkan menjadi tiga yaitu menurut golongan, menurut sifat, dan menurut lembaga pemungutnya. 1) Menurut golongan, pajak dapat dikelompokkan menjadi: a. Pajak langsung adalah pajak yang harus dipikul atau ditanggung oleh Wajib Pajak dan tidak dapat dilimpahkan atau dibebankan kepada oranglain atau pihak lain. Pajak harus menjadi beban Wajib Pajak bersangkutan. Contoh: Pajak Penghasilan (PPh), PP dibayar atau ditanggung oleh pihak -pihak tertentu yang memperoleh penghasilan tersebut. b. Pajak tidak langsung adalah pajak yang pada akhirnya dapat dibebankan atau dilimpahkan kepada orang lain atau pihak ketiga. Pajak tidak langsung terjadi jika terdapat suatu kegiatan, peristiwa, atau perbuatan yang menyebabkan terutangnya pajak, misalnya terjadi penyerahan barang atau jasa. Contoh: Pajak Pertambahan Nilai (PPN), PPN terjadi karena terjadi pertambahan nilai terhadap barang atau jasa. Pajak ini dibayarkan oleh produsen atau pihak yang menjual barang tetapi dapat dibebankan kepada konsumen. 2) Menurut sifatnya, pajak dapat dikelompokkan menjadi dua, yaitu: a. Pajak subjektif yaitu pajak yang pengenaannya memperhatikan keadaan pribadi Wajib Pajak atau pengenaan pajak yang memperhatikan subjeknya. Contoh: Pajak Penghasilan (PPh). Dalam PPh terdapat Subjek Pajak (Wajib Pajak) orang pribadi. Pengenaan $\mathrm{PPh}$ untuk orang pribadi tersebut memperhatikan keadaan pribadi Wajib Pajak (status perkawinan), banyaknya anak, tanggungan, dan lainnya yang selanjutnya digunakan untuk menentukan besarnya Penghasilan Tidak Kena Pajak (PTKP). b. Pajak objektif merupakan pajak yang 
pengenaanya memperhatikan objeknya baik berupa benda, keadaan, perbuatan, atau peristiwa yang mengakibatkan timbulnya kewajiban membayar pajak, tanpa memperhatikan keadaan pribadi Subjek Pajak (Wajib Pajak) maupun tempat tinggal. Contoh: Pajak Pertambahan Nilai (PPN) dan Pajak atas Barang Mewah (PPnBM), serta Pajak Bumi dan Bangunan. 3) Menurut Lembaga Pemungut, dibagi menjadi dua, yaitu: a. Pajak Pusat adalah pajak yang dipungut oleh pemerintah pusat dan digunakan untuk membiayai rumah tangga negara, contohnya Pajak Bumi dan Bangunan (PBB), PPh, PPN, PPnBM dan Bea Materai. b. Pajak Daerah, adalah pajak yang dipungut oleh pemerintah daerah untuk membiayai rumah tangga daerah, contohnya Pajak Reklame.

Menurut Mardiasmo (2013), menyatakan ada beberapa sistem pemungutan pajak yang terdiri sebagai berikut: 1) Official Assessment System Adalah suatu sistem pemungutan yang memberi wewenang kepada pemerintah (fiskus) untuk menentukan besarnya pajak yang terutang oleh Wajib Pajak. Ciri-ciri official assessment system adalah sebagai berikut: Wewenang untuk menentukan besarnya pajak terutang ada pada fiskus, Wajib Pajak bersifat pasif, Utang yang timbul setelah dikeluarkan surat ketetapan pajak oleh fiskus. 2) Self Assessment System Adalah suatu sistem pemungutan pajak yang memberi wewenang kepada Wajib Pajak untuk menentukan sendiri besarnya pajak yang terutang. Ciri-cirinya adalah sebagai berikut: Wewenang untuk menentukan besarnya pajak terutang ada pada Wajib Pajak sendiri, Wajib Pajak aktif, mulai dari menghitung, menyetor, dan melaporkan sendiri pajak yang terutang, Fiskus tidak ikut campur dan hanya mengawasi. 3) With Holding System Adalah suatu sistem pemungutan pajak yang wajib memberi wewenang kepada pihak ketiga (bukan fiskus dan bukan Wajib Pajak yang bersangkutan) untuk menentukan besarnya pajak yang terutang oleh Wajib Pajak. Ciri-cirinya: wewenang menentukan besarnya pajak yang terutang ada pada pihak ketiga, pihak selain fiskus dan wajib pajak.

Dari 3 sistem pemungutan pajak di atas, Indonesia merupakan negara yang menganut self asessment system dimana wajib pajak diminta aktif dalam menghitung, menyetor, dan melaporkan sendiri pajak yang terutang. Hal ini membuat Wajib Pajak jadi lebih mandiri dalam menjalankan kewajibannya dan Dirjen Pajak atau fiskus hanya tinggal mengawasinya saja.

Menurut Etty Muyassaroh (2012) Pajak Penghasilan (PPh) adalah Pajak yang dikenakan terhadap orang pribadi dan badan, berkenaan dengan penghasilan yang diterima atau diperoleh selama satu tahun pajak.

Pengertian Pajak Penghasilan (PPh) Pasal 21 berdasarkan Peraturan Direktur Jenderal Pajak Nomor PER-31/PJ/2012 adalah pajak atas penghasilan berupa gaji, upah, honorarium, tunjangan dan pembayaran lain dengan nama dan dalam bentuk apa pun sehubungan dengan pekerjaan atau jabatan, jasa, dan kegiatan yang dilakukan oleh orang pribadi subyek pajak dalam negeri.

Dari pendapat diatas, menarik kesimpulan bahwa Pajak Penghasilan Pasal 21 adalah Pajak yang dikenakan terhadap orang pribadi atau badan atas penghasilan yang didapat sehubungan dengan pekerjaan atau kegiatan yang dilakukan oleh orang pribadi subyek pajak dalam negeri.

Dalam Peraturan Nomor PER31/PJ/2012, yang termasuk Objek $\mathrm{PPh}$ Pasal 21 antara lain: 1) Penghasilan yang diterima atau diperoleh Pegawai Tetap, baik berupa penghasilan yang Bersifat Teratur maupun Tidak Teratur; 2. Penghasilan yang diterima atau diperoleh penerima pensiun secara teratur berupa uang pensiun atau penghasilan sejenisnya; 3. Penghasilan berupa uang pesangon, uang manfaat pensiun, tunjangan hari tua, atau jaminan hari tua 
yang dibayarkan sekaligus, yang pembayarannya melewati jangka waktu 2 (dua) tahun sejak pegawai berhenti bekerja; 4) Penghasilan Pegawai Tidak Tetap atau Tenaga Kerja Lepas, berupa upah harian, 5) upah mingguan, upah satuan, upah borongan atau upah yang dibayarkan secarabulanan; 6) Imbalan kepada Bukan Pegawai, antara lain berupa honorarium, komisi, fee, danimbalan sejenisnya dengan nama dan dalam bentuk apapun sebagai imbalansehubungan jasa yang dilakukan; 7) Imbalan kepada peserta kegiatan, antara lain berupa uang saku, uang representasi, uang rapat, honorarium, hadiah atau penghargaan dengan nama dan dalam bentuk apapun, dan imbalan sejenis dengan nama apapun; 8) Penghasilan berupa honorarium atau imbalan yang bersifat tidak teratur yangditerima atau diperoleh anggota dewan komisaris atau dewan pengawas yang tidak merangkap sebagai Pegawai Tetap pada perusahaan yang sama; 9) Penghasilan berupa jasa produksi, tantiem, gratifikasi, bonus atau imbalan lainyang bersifat tidak teratur yang diterima atau diperoleh mantan pegawai; atau 10) Penghasilan berupa penarikan dana pensiun oleh peserta program pensiun yangmasih berstatus sebagai pegawai, dari dana pensiun yang pendiriannya telahdisahkan oleh Menteri Keuangan.

\section{Dasar Pengenaan Pajak}

Berdasarkan Peraturan Direktur Jenderal Pajak Nomor PER-31/PJ/2012 Tentang Pedoman Teknis Tata Cara Pemotongan, Penyetoran dan Pelaporan Pajak Penghasilan Pasal 21 Dan Atau Pasal 26 Sehubungan Dengan Pekerjaan, Jasa Dan Kegiatan Orang Pribadi, maka dasar pengenaan dan pemotongan Pajak Penghasilan pasal 21 (PPh 21) adalah sebagai berikut: 1) Pegawai Tetap; 2) Penerima pensiun berkala; 3) Pegawai Tidak Tetap yang penghasilannya dibayar secara bulanan atau jumlah kumulatif penghasilan yang diterima dalam 1 (satu) bulan kalender telah melebihi Rp. 2,025,000.00 (dua juta dua puluh lima ribu rupiah); 5) Bukan Pegawai yang menerima imbalan yang bersifat berkesinambungan.

\section{Penghasilan dari Pekerjaan}

Penghasilan yang diterima oleh Wajib Pajak dapat dikelompokkan menjadi dua, yaitu penghasilan dari menjalankan usaha atau business income dan penghasilan dari kegiatan melakukan pekerjaan atau employment income. Penghasilan dari menjalankan usaha dapat dilakukan oleh pribadi atau badan hukum, sedangkan penghasilan dari kegiatan melakukan pekerjaan hanya dapat dilakukan oleh orang pribadi.

Employment Income merupakan penghasilan yang diperoleh orang pribadi sehubungan dengan kegiatan dalam melakukan pekerjaan, jasa, dan kegiatan lain. Jenis Employment Income dapat dibagi menjadi dua, yaitu: 1) Penghasilan sebagai pegawai atau penghasilan dari penyerahan jasa orang pribadi tidak bebas atau penghasilan sebagai karyawan. 2) Penghasilan dari pekerjaan bebas, misalnya penghasilan dari jasa professional yang independen. 3) Apabila diperhatikan pengertian employment income pada intinya menyangkut semua penghasilan yang diterima karyawan termasuk fasilitas dan penggantian yang diterima sehubungan dengan adanya hubungan pekerjaan.

\section{Manajemen Pajak}

Pemerintah saat ini melakukan upaya yang serius dalam bidang perpajakan. Karena itu pengusaha harus menanggapinya dengan cara serius juga, yaitu dengan menempuh manajemen pajak. Bagaimanapun pajak bagi perusahaan tetap sebagai "biaya". Artinya sekecil apapun pajak yang harus dibayar oleh perusahaan, tetap saja akan 
mengurangi laba yang diterima oleh perushaan. Jika pengelolaan pajak tidak dilakukan dengan baik, kemungkinan dikemudian hari perusahaan terpaksa gulung tikar.

Upaya melakukan penghematan pajak secara legal dapat dilakukan dalam manajemen pajak. Secara umum manajemen pajak dapat didefinisikan sebagai sarana untuk memenuhi kewajiban perpajakan dengan benar tetapi jumlah pajak yang dibayar dapat ditekan serendah mungkin untuk memperoleh laba dan likuidasi yang diharapkan (Suandy,2014).

Tujuan manajemen pajak dapat dibagi dua, yaitu: 1) Menerapkan peraturan perpajakan secara benar. 2) Usaha efisiensi untuk mencapai laba dan likuiditas yang seharusnya.

Tujuan manajemen pajak dapat dicapai melalui fungsi-fungsi manajemen pajak yang terdiri atas: 1) Perencanaan pajak (tax planning). 2) Pelaksanaan kewajiban perpajakan (tax implementation). 3) Pengendalian pajak (tax control).

Manajemen pajak merupakan bagian dari manajemen keuangan. Manajemen keuangan yang efisien membutuhkan suatu tujuan dan sasaran yang akan digunakan sebagai patokan dalam memberikan penilaian atas efisiensi keputusan keuangan. Dengan demikian tujuan manajemen pajak harus sejalan dengan tujuan manajemen keuangan, yaitu memperoleh likuiditas dan laba yang memadai.

\section{Manajemen Pajak Penghasilan Pasal 21}

Salah satu manajemen pajak yang biasanya dilakukan oleh perusahaan adalah pada pajak penghasilan pasal 21 . Untuk pajak tersebut perusahaan melakukan perencanaan dalam pemilihan metode perhitungan ataupun dalam bentuk pemberian tunjangan terhadap karyawan, ditanggung perusahaan, dan ditunjang oleh perusahaan. Sedangkan untuk pemberian tunjangan terdapat 2 jenis yang biasanya diberikan oleh perusahaan yaitu benefit in cash dan benefit in kind atau natura.

\section{Perencanaan Pajak}

Perencanaan pajak menurut Erly Suandy (2014), "Perencanaan pajak merupakan langkah awal dalam manajemen pajak. Strategi penghematan pajak disusun pada saat perencanaan. Karena itu, pada tahap ini dilakukan pengumpulan dan penelitian terhadap peraturan perpajakan agar dapat diseleksi jenis tindakan penghematan pajak yang akan dilakukan.

Perencanaan pajak menurut Harnanto (2013), "Perencanaan pajak yaitu minimisasi Penghasilan Kena Pajak dalam tahun berjalan dapat diinterpretasi sebagai maksimisasi Penghasilan Kena Pajak di kemudian hari. Proses minimisasi Penghasilan Kena Pajak atau pajak penghasilan yang terutang dalam tahun berjalan dapat dilakukan dengan mengidentifikasi dan memanfaatkan tarif pajak yang relevan dalam membuat keputusan-keputusan menyangkut aktivitas operasi, investasi dan pendanaan."

Pengertian perencanaan pajak yang dikemukakan oleh Chairil Anwar (2013), "Perencanaan pajak adalah proses mengorganisasi usaha wajib pajak orang pribadi maupun badan usaha sedemikian rupa dengan memanfaatkan berbagai celah kemungkinan yang dapat ditempuh oleh perusahaan dalam koridor ketentuan peraturan perpajakan (loopholes), agar perusahaan dapat membayar pajak dalam jumlah minimum".

Dari beberapa definisi di atas, menarik kesimpulan bahwa perencanaan pajak dapat dimaknai sebagai suatu kegiatan untuk merekayasa agar beban pajak serendah mungkin dengan memanfaatkan celah-celah aturan yang ada, tetapi tidak secara eksplisit melawan 
undang-undang, dan tidak dapat dipersalahkan sebagai upaya penggelapan pajak.

Tujuan pokok yang seharusnya dicapai oleh para eksekutif perusahaan adalah memberikan keuntungan yang maksimum untuk jangka panjang (longterm return) kepada para pemodal atau pemegang saham yang telah menginvestasikan kekayaan dan mempercayakan pengelolaannya kepada perusahaan. Keuntungan tersebut harus diperoleh dengan mematuhi peratiran atau ketentuan perpajakan, baik pajak daerah maupun pajak pusat, bahkan ketentuan pajak internasional. Sebagai wajib pajak, setiap perusahaan harus mematuhi dan melaksanakan kewajibankewajiban pajaknya sesuai dengan peraturan atau ketentuan yang berlaku.

Pada umumnya, ukuran kepatuhan memenuhi kewajiban perpajakan biasanya diukur dan dibandingkan dengan besar kecilnya penghematan pajak (tax saving), penghindaran pajak (tax avoidance) dan penyelundupan pajak (tax evasion) yang kesemuanya itu bertujuan untuk meminimalkan beban pajak, melalui beberapa cara anatara lain melalui pengecualian-pengecualian, pengurangan-penguranagan, insentif pajak, penghasilaan yang bukan objek pajak, penangguhan pengenaan pajak, pajak ditangguhkan negara sampai kepada kerja sama dengan aparat perpajakan, suap-menyuap dan pemalsuan-pemalsuan.

Terlihat bahwa perencanaan pajak melalui penghindaran pajak merupakan satu-satunya cara legal yang dapat ditempuh oleh Wajib Pajak dalam rangka mengefisiensikan pembayaran pajaknya. Ide dasarnya adalah usaha pengaturan terlebih dahulu semua aktivitas perusahaan guna menghindarkan dampak perpajakan sebanyak mungkin atau dengan perkataan lain peluang untuk perencanaan pajak yang efektif, terdapat lebih besar kemungkinannya apabila hal tersebut dipertimbangkan sebelum transaksi tersebut dilaksanakan, dibandingkan apabila pertimbangannya dilakukan setelah terjadi transaksi. Dalam hal ini tentunya sangat tergantung kepada para manajer, sampai sejauh mana para manajer tersebut mewaspadai secara konstan alternatif-alternatif penghematan pajak pada setiap tindakan yang akan diambilnya.

Dapat disimpulkan bahwa suatu perencanaan pajak yang efektif tidak tergantung kepada seseorang ahli pajak yang profesional, akan tetapi sangat tergantung kepada kesadaran dan keterlibatan pada pengambul keputusan akan adanya dampak pajak yang melekat pada setiap aktivitas perusahaanya. Tujuan tax planning secara lebih khusus ditujukan untuk memenuhi hal-hal sebagai berikut: a. Menghilangkan atau menghapus pajak sama sekali. b. Menghilangkan atau menghapus pajak dalam tahun berjalan. c. Menunda pengakuan penghasilan. d. Mengubah penghasilan rutin berbentuk capital gain. e. Memperluas bisnis atau melakukan ekspansi ussaha dengan membentuk badan usaha baru. f. Menghindari pengenaan pajak ganda. g. Menghindari bentuk penghasilan yang bersifat rutin atau teratur atau membentuk, memperbanyak atau mempercepat pengurangan pajak.

\section{Prinsip Perencanaan Pajak}

Perpajakan sangat penting untuk diketahui, tetapi sulit untuk dipelajari. Dengan menguasai prinsip dasar perpajakan dan penerapannya dalam dunia usaha, keputusan bisnis akan menjadi lebih baik. Berikut tiga faktor yang bisa memotivasi manajemen untuk berusaha mengurangi beban pajak bagi organisasi/perusahaan. a. Rincian konsep perpajakan sangat kompleks sehingga tidak mudah dipahami, b. Biaya kelengkapan administrasi pajak, seperti pengisian Surat Pemberitahuan Masa / 
Tahunan (SPT), dan c. Beban konsultan pajak yang cukup mahal.

Sebagian perusahaan berpikir bahwa dengan memperkecil beban pajak maka tujuan perencanaan pajak sudah berhasil. Hal ini tidak sepenuhnya benar karena beban pajak tidak semata-mata dikarenakan atas keuntungan usaha dan kekayaan wajib pajak. Sebaiknya, manajemen juga harus memperhitungkan keuntungan dari nilai tunai uang (time value of money), seperti menunda pembayaran pajak di belakang hari atau mengenakan tarif pajak yang berbeda (tax rate arbitrage) melalui skema harga transfer (transfer price).

Perencanaan pajak yang baik dapat menjadi sumber penyediaan modal kerja perusahaan. Berikut ini ruang lingkup perencanaan pajak. 1) Upaya legal untuk menghemat beban pajak dengan memanfaatkan hal-hal yang belum diatur dalam peraturan perpajakan dengan berbagai metode berikut ini: a. Maximizing tax deductable: upaya membebankan biaya-biaya usaha, baik yang dikeluarkan sceara tunai maupun dalam bentuk non tunai semaksimal mungkin yang diperbolekan undangundang, b. Legal standing of corporate entity: mencari bentuk usaha yang tepat, sepertu $\mathrm{CV} / \mathrm{Fa}$ atau PT, dengan tujuan menghemat pajak, c. Melakukan konglomerasi usaha: berupa penyatuan bentuk usaha secara vertikal dan horizontal, d. Memecah satu unit usaha menjadi beberapa perusahaan, dan e. Tax deferred income: menunda pengakuan penghasilan. 2) Mengorganisasi usaha wajib pajak atau kelompok wajib pajak sehingga utang pajak, baik PPh maupun pajak-pajak lainnya, dalam posisi sehemat mungkin sesuai ketentuan Undang- Undang Pajak. 3) Mendeteksi cacat teoritis dari ketentuan UndangUndangPajak untuk menemukan cara penghindaran pajak yang dapat menghemat pembayaran pajak.

\section{Penghindaran Pajak Versus Penyelundupan}

Pembayaran sanksi yang tidak seharusnya terjadi merupakan pemborosan sumber daya perusahaan. Penghindaran pemborosan terebut merupakan optimalisasi alokasi sumber daya perusahaan ke arah yang lebih produktif dan efisien sehingga dapat memaksimalkan kinerja dengan benar dan mengerjakan yang seharusnya, selain harus bekerja keras dan bekerja secara cerdas. Sanksi administrasi dapat berupa denda, bunga, maupun kenaikan. Sanksi tersebut merupakan denda keuangan (financial penalty) yang merupakan pemborosan dana. Sedangkan sanksi pidana dapat berupa pidana penjara dan/atau denda keuangan.

Sistem perpajakan menganut prinsip substansi mengalakan bentuk formal (substance over from rule). Walaupun perushaaan telah memenuhi kewajiban perpajakan secara formal, tetapi kalau ternyata substansi menunjukkan lain atau motivasi rekayasa tidak sesuai dengan jiwa dari ketentuan perpajakan, administrasi pajak (fiskus) dapat menganggap bahwa Wajib Pajak kurang patuh dalam memenuhi kewajiban perpajakannya.

Hal - hal yang harus diperhatikan dalam suatu perencanaan pajak (tax planning), yaitu: a. Tidak melanggar ketentuan perpajakan. b. Perencanaan pajak (tax planning) merupakan bagian yang tidak terpisahkan dari perencanaan menyeluruh (global strategy) perusahaan. c. Bukti-bukti pendukungnya memadai, misalnya dukungan perjanjian (agreement), faktur (invocie) dan juga perlakuan akuntansinya (accounting treatment).

Suatu perencanaan pajak disebut juga seagai perbuatan penghindaran pajak yang sukses, haruslah dengan jelas dibedakan dengan perbuatan penyelundupan pajak. Semua ahli sependapat bahwa sesungguhnya anatara 
penghindaran pajak dan penyelundupan pajak terdapat perbedaan yang fundamental, akan tetapi kemudian ternyata bahwa perbedaan tersebut menjadi kabur, baik secara teori maupun aplikasinya. Secara konseptual, justru dalam menetukan perbedaaan antara penghindaran pajak dan penyelundupan pajak, kesulitannya terletak pada penentuan perbedaannya, akan tetapi berdasarkan konsep perundangundangan, garis pemisahnya adalah anatara melanggar undang-undang (unlawful) dan tidak melanggar undangundang (lawful).

Walaupun pada dasarnya anatara penghindaran pajak dan penyelundupan pajak mempunyai sasaran yang sama, yaitu mengurangi beban pajak, akan tetapi cara penyelundupan pajak jelasjelas merupakan perbuatan ilegal dalam usaha mengurangi beban pajak tersebut.

Penyelundupan pajak dan penghindaran pajak mengandung arti sebagai usaha yang dilakukan oleh Wajib Pajak, apakah berhasil atau tidak untuk mengurangi atau sama sekali menghapus utang pajak yang berdasarkan ketentuan yang berlaku sebagai pelanggaran terhadap perundang-undangan perpajakan. Penghindaran pajak merupakan usaha yang sama, yang tidak melanggar ketentuan-ketentuan perundang-undangan perpajakan.

\section{Peraturan Perpajakan yang Memungkinkan Terjadinya Perencanaan Pajak}

\section{Dasar Hukum dan Peraturan Pelaksanaan}

Untuk menjamin terlaksananya fungsi pajak sebagai penghimpun dana (budgetair) dari sektor pribadi ke sektor umum diperlukan perangkat pasti dan mengikat. Kepastian hukum diperlukan untuk meminimalisasi perlawanan yang timbul pada saat pelaksanaan pemungutan pajak. Dalam undang- undang diatur mengenai subjek pajak dan bukan subjek pajak, objek pajak dan bukan objek pajak, tarif pajak, pembayaran serta ketentuan lain yang diperlukan untuk Pajak Penghasilan (PPh) pasal 21.

Sebagaimana diketahui bahwa transaksi pemotongan pajak penghasilan $(\mathrm{PPh})$ diatur dalam Peraturan Direktur Jenderal Pajak Nomor: PER - 31/PJ/2012 dan juga Undang - Undang Republik Indonesia No. 36 Tahun 2008 tentang perubahan keempat atau Undang-Undang No. 17 tahun 1983 tentang pajak Penghasilan (PPh). Khususnya untuk pemotongan Pajak Penghasilan (PPh) Pasal 21 Pedoman yang digunakan antara lain: a. Undang-Undang No. 36 Tahun 2008 tentang perubahan keempat atas Undang-Undang No. 7 Tahun 1983 tentang Pajak Penghasilan. b. Peraturan Direktur Jenderal Pajak No. PER 31/PJ/2012 tentang Pedoman Teknis Tata Cara Pemotongan, Penyetoran dan Pelaporan Pajak Penghasilan (PPh) Pasal 21 dan/atau Pajak Penghasilan Pasal 26 Sehubungan dengan Pekerjaan, Jasa, dan Kegiatan Orang Pribadi. c. Peraturan Menteri Keuangan RI No. 162/PMK.011/2012 mengenai penyesuaian besarnya penghasilan tidak kena pajak atau PTKP 2013.

\section{Pengurang yang di perbolehkan}

Penerima penghasilan yang berstatus sebagai karyawan tetap atau penerima dana pensiun yang dibayarkan berkala dikenakan pajak penghasilan pasal 21. Bagi golongan penerima penghasilan tersebut berlaku pengurangan yang diperbolehkan untuk menghitung penghasilan netto atau Penghasilan Kena Pajak (PKP). Untuk mengetahui besarnya penghasilan netto pegawai tetap, penghasilan bruto pegawai tersebut dikurangi dengan: a. Biaya Jabatan; Biaya Jabatan adalah biaya untuk menagih, mendapatkan dan memelihara penghasilan dari suatu 
pekerjaan, tanpa memandang apakah pegawai tersebut memiliki jabatan atau tidak. Biaya Jabatan ditentukan dalam peraturan Menteri Keuangan No. 250/PMK.03/2008 Tentang Besarnya Biaya Jabatan atau Biaya Pensiun yang dapat dikurangkan dari Penghasilan Bruto Pegawai Tetap atau Pensiunan sebesar 5\% dari Penghasilan Bruto, Setinggi-tingginya Rp. $6,000,000.00$ setahun atau Rp 500,000.00 sebulan. b. Iuran Pensiun; Iuran Pensiun yang dibayarkan karyawan yang terkait pada gaji, yang dibayarkan kepada dana pensiun yang pendiriannya telah disahkan oleh menteri keuangan dapat dijadikan sebagai pengurang penghasilan bruto. c. Penghasilan Tidak Kena Pajak (PTKP); Besarnya Penghasilan Tidak Kena Pajak (PTKP) diatur dalam Peraturan Menteri Keuangan RI No. 162/PMK.011/2012 sesuai yang tercantum dalam Tabel 1 dibawah ini.

Tabel 1. Penghasilan Tidak Kena Pajak (PTKP)

\begin{tabular}{|c|c|c|c|}
\hline No & Keterangan & Setahun & Sebulan \\
\hline 1 & Untuk Diri Wajib Pajak Pribadi & IDR $24,300,000.00$ & IDR 2,025,000.00 \\
\hline 2 & $\begin{array}{l}\text { Tambahan untuk Wajib Pajak } \\
\text { Kawin }\end{array}$ & IDR $2,025,000.00$ & IDR $168,750.00$ \\
\hline 3 & $\begin{array}{l}\text { Tambahan untuk anak (paling } \\
\text { banyak } 3 \text { orang) }\end{array}$ & IDR $2,025,000.00$ & IDR $168,750.00$ \\
\hline
\end{tabular}

Sumber: Peraturan Menteri Keuangan RI Nomor 162/PMK.011/2012

Pengurang yang diperbolehkan bagi wajib pajak badan untuk menentukan penghasilan netto sebagai mana yang diatur dalam Undang-Undang No. 36 Tahun 2008 tentang Pajak Penghasilan (PPh) adalah sebagai berikut: 1) Biaya yang secara langsung atau tidak langsung berkaitan dengan kegiatan usaha. 2) Penyusutan atas pengeluaran untuk memperoleh harta berwujud dan amortisasi atas pengeluran untuk memperoleh hak dan atas biaya lain yang mempunyai masa manfaat lebih dari 1 (satu) tahun. 3) Iuran kepada dana pensiun yang pendiriannya telah disahkan oleh Menteri Keuangan. 4) Kerugian karena penjualan atau pengalihan harta yang dimiliki dan digunakan dalam perusahaan atau yang dimiliki untuk mendapatkan, menagih, dan memelihara penghasilan. 5) Kerugian selisih kurs mata uang asing. 6) Biaya penelitian dan pengembanaan perusahaan yang dilakukan di Indonesia. 7) Biaya beasiswa, magang, dan pelatihan 8) Piutang yang nyata-nyata tidak dapat ditagihkan dengan syarat tertentu.
9) Sumbangan dalam rangka penanggulangan bencana nasional yang ketentuannya diatur dalam peraturan pemerintah. 10) Biaya pembangunan infrasruktur social yang ketentuannya diatur dengan peraturan pemerintah. 11) Sumbangan fasilitas pendidikan yang ketentuannya diatur dengan peraturan pemerintah. 12) Sumbangan dalam rangka pembinaan olahraga yang ketentuannya diatur dalam peraturan pemerintah.

\section{Tarif Pajak}

Menurut Rismawati Sudirman dan Antong Amiruddin (2012), "Tarif pajak adalah ketentuan persentase (\%) atau jumlah (rupiah) pajak yang harus dibayar oleh Wajib Pajak sesuai dengan dasar pajak atau objek pajak."

Menurut Prasetyono dalam Buku Pintar Pajak (2012), "Tarif pajak adalah Dalam pemungutan pajak harus ditetapkan terlebih dahulu jenis tarif yang dipergunakan, karena tarif ini berhubungan erat dengan fungsi pajak, yaitu fungsi budget dan fungsi mengatur." 
Oleh karena itu dapat disimpulkan bahwa tarif pajak adalah persentasi tertentu yang ditentukan oleh undangundang dalam rangka menentukan besarnya pajak terutang. Sehubungan dengan kewajiban untuk membayar pajak, dalam menghitung besarnya pajak terutang yang harus dibayarkan ditetapkan tarif pajak bagi wajib pajak orang pribadi berdasarkan pasal 17 undang - undang PPh No. 36 tahun 2008. Sesuai Tabel. 2 dibawah ini:

Tabel 2. Tarif Pajak Penghasilan Wajib Pajak Orang Pribadi

\begin{tabular}{ccc}
\hline No & Keterangan & Tarif \\
\hline 1 & Rp - s/d Rp 50.000.000,- & $5 \%$ \\
2 & $R p 50.000 .000,-$ s/d 250.000.000, - & $15 \%$ \\
3 & $R p 250.000 .000,-$ s/d 500.000.000, - & $25 \%$ \\
4 & $>$ Rp 500.000.000, - & $30 \%$ \\
\hline
\end{tabular}

Sumber Undang - Undang PPh No. 36 Tahun 2008

Bagi penerima penghasilan yang dipotong $\mathrm{PPh}$ Pasal 21 yang tidak memiliki Nomor Pokok Wajib Pajak (NPWP), akan dikenakan pemotongan $\mathrm{PPh}$ Pasal 21 dengan tarif yang lebih tinggi 20\% (dua puluh persen) daripada tarif yang diterapkan terhadap Wajib Pajak yang memiliki NPWP. Sehingga, Jumlah PPh Pasal 21 yang harus dipotong adalah sebesar $120 \%$ (seratus dua puluh persen) dari jumlah PPh Pasal 21 yang seharusnya dipotong dan bersifat tidak final.

Dalam hal pegawai tetap atau penerima pensiun berkala, sebagai penerima penghasilan yang telah dipotong PPh Pasal 21 dengan tarif yang lebih tinggi, disarankan untuk segera mendaftarkan diri paling lama sebelum pemotongan $\mathrm{PPh}$ Pasal 21 untuk masa pajak Desember, PPh Pasal 21 yang telah dipotong asat selisih pengenaan tarif sebesar 20\% (dua puluh persen) lebih tinggi tersebut diperhitungkan dengan PPh Pasal 21 yang terutang untuk bulanbulan selanjutnya setelah memiliki NPWP.

\section{Tahapan Dalam Membuat Perencanaan Pajak}

Menurut Suandy (2013) dalam arus globalisasi dan tingkat persaingan yang semakin tinggi, seorang manajer dalam membuat suatu perencanaan pajak sebagaimana strategi perencanaan perusahaan secara keseluruhan harus memperhitungkan adanya kegiatan yang bersifat lokal maupun internasional. Agar perencanaan pajak dapat berhasil sesuai dengan yang diharapkan, maka rencana itu seharusnya dilakukan melalui berbagai tahapan, yaitu: a. Menganalisis informasi yang ada. b Membuat satu model atau lebih rencana kemungkinan besarnya pajak. c. Mengevaluasi pelaksanaan rencana pajak. d. Mencari kelemahan dan kemudian memperbaiki kembali rencana pajak. e. memutakhirkan rencana pajak

\section{Menganalisis Informasi yang Ada}

Tahap pertama dari proses pembuatan tax planning adalah menganalisis komponen yang berbeda atas pajak yang terlibat dalam suatu proyek dan menghitung seakurat mungkin beban pajak yang harus ditanggung.

Hal ini hanya bisa dilakukan dengan mempertimbangkan masingmasing elemen dari pajak, baik secara sendiri-sendiri maupun secara total pajak yang harus dapat dirumuskan sebagai perencanaan pajak yang paling efisien. Penting juga untuk memperhitungkan kemungkinan besarnya penghasilan dari suatu proyek dan pengeliaran- 
pengeluaran lain di luar pajak yang mungkin terjadi. Untuk itu, seorang maanjer perpajakan harus memperhatikan faktor-faktor baik internal maupun eksternal, yaitu: 1) Fakta yang relevan; Dalam arus globalisasi dan tingkat persaingan yang semakin tinggi, seorang manajer perusahaan dalam melakukan perencanaan pajak untuk perusahaannya dituntut untuk benar-benar menguasai situasi yang dihadapi. Baik dari segi internal maupun eksternal dan selalu memutakhirkan dengan perubahanperubahan yang terjadi agar perencanaan pajak dapat dilakukan secara tepat dan menyeluruh terhadap situasi maupun transaksi-transaksi yang mempunyai dampak perpajakan. Sebagai contoh, ruang lingkup kegiatan penjualan produksinya harus diidentifikasikan apakah suatu produk yang akan dijual tergolong sebagai objek pengenaan pajak penjualan barang mewah atau tidak. 2) Faktor - Faktor Pajak; Dalam menganalisi setiap permasalahan yang dihadapi dalam penyusunan perencanaan pajak tidak terlepas dari dua hal utama yang berkaitan dengan faktor-faktor: a. Sistem perpajakan nasional yang dianut oleh suatu Negara. b. Sikap fiskus dalam menafsirkan peraturan perpajakan baik undang-undang domestik maupun kebijakan perpajakan. 2) Faktor non Pajak; Beberapa faktor non pajak yang relevan untuk diperhatikan dalam penyusunan suatu perencanaan pajak, antara lain: a. Masalah badan hokum; Pemilihan bentuk badan usaha yang diusulkan sering dibuat sebagai fungsi dari seluruh peraturan (baik untuk pajak maupun nonpajak), dalam rangka administrasi pembentukan dan pembubaran badan hukum yang bersangkutan. b. Masalah mata uang dan nilai tukar; Masalah nilai tukar mata uang mempunyai dampak yang besar terhadap kondisi keuangan suatu perusahaan. Nilai tukar mata uang yang berfluktuasi atau tidak stabil memberikan resiko usaha yang cukup tinggi. Dari dampak finansial tentunya berakibat pada posisi laba rugi, terutama bila terdapat banyak transaksi ekspor atau impor maupun pinjaman dalam bentuk mata uang asing. Disini diperlukan strategi bisnis dalam menangani jual beli antara induk perusahaan dengan anak perusaaan atau dengan berbagai mitra usaha. Untuk mengatasi kerugian fluktuasi nilai mata uang asing biasanya dilakukan pasar kontrak berjangka khusus (forward market), SWAP, maupun pasar kontrak berjangka di bursa (future market). c. Masalah pengawasan devisa; Sistem pengawasan devisa (exchange control) yang dianut suatu negara menjadi bahan pertimbangan penting terutama jika suatu negara menganut pembatasan atau larangan untuk mengadakan pertukaran atau transfer dana dari transaksi internasional, maupun adanya larangan untuk meminjam uang atau menarik uang dari luar tanpa seizin bank sentral atau menteri keuangan. d. Masalah program insentif investasi; Program insentifinsentif memberikan pilihan bagi Wajib Pajak untuk melakukan investasi atau pemekaran usaha pada suatu lokasi atau negara tertentu. Insentif investasi yang merangsang bisa berupa pemberian pinjaman dengan tarif bunga rendah, ataupun adanya pemberian bantuan (grants) dari pemerintah. e. Masalah faktor non pajak lainnya; Faktor non pajak lainnya seperti hukum dan sistem administrasi yang berlaku, kestabilan ekonomi dan politik, tenaga kerja, pasar, ada atau tidaknya tenaga profesional, fasilitas perbankan, iklim usaha, bahasa, sistem akuntansi, dan lain-lain harus dipertimbangkan juga dalam penyusunan perencanaan pajak terutama berkaitan dengan pemilihan lokasi investasi, apakah berupa cabang, anak perusahaan, atau lainnya. 


\section{Evaluasi Atas Perencanaan Pajak}

Perencanaan pajak sebagai suatu perencanaan yang merupakan bagian kecil dari seluruh perencanaan strategis perusahaan, oleh karena itu perlu dilakukan evaluasi untuk melihat sejauh mana hasil pelaksanaan suatu perencanaan pajak terhadap beban pajak, perbedaan laba kotor, dan pengeluaran selain pajak atas berbagai alternatif perencanaan. Variabel-variabel tersebut akan dihitung seakurat mungkin dengan hipotesis sebagai berikut: 1. Bagaimana jika rencana tersebut tidak dilaksanakan; 2. Bagaimana jika rencana tersebut direncanakan dan berhasil dengan baik; 3. Bagaimana jika rencana tersebut dilaksanakan tapi gagal.

Namun perlu diperhatikan bahwa ada tambahan biaya hukum dan lainlainnya yang mungkin terjadi apabila pihak otoritas pajak tidak setuju dengan pos-pos yang dikurangkan dari penghitungan pajak yang dapat dibawa ke pengadilan.

Begitu juga mengenai nilai waktu dan uang. Bila perencanaan pajak yang dilaksanakan semata-mata hanya untuk menunda pembayaran bukan untuk mengurangi beban pajak, maka seharusnya didiskontokan terhadap nilai sekarang dan dibandingkan dengan biaya-biaya yang dikeluarkan sekarang. Dengan kata lain, dilihat nilai sekarang atas penghemaran penundaan pajak berbagai tahun di kemudian hari dikurangi nilai sekarang atas biaya yang dikeluarkan untuk suatu perencanaan pajak.

\section{Memutakhirkan Rencana Pajak}

Meskipun suatu rencana pajak telah dilaksanakan dan proyek juga telah berjalan, tetap perlu diperhitungkan setiap perubahan yang terjadi, baik dari undang-undang maupun pelaksanaanya (negara dimana aktivitas tersebut dilaksanakan) yang dapat berdampak terhadap komponen suatu perjanjian. Namun sayangnya, informasi mengenai perubahan yang terjadi diluar negeri atas berbagai macam pajak maupun aktivitas bisnis sering kali sangat terbatas. oleh karena itu, ketika memberikan masukan kepada konsulen luar negeri sehubungan dengan rencana perubahan-perubahan yang akan segera terjadi dalam undangundang dan pelaksanaanya, juga harus ditanyakan mengenai dampaknya terhadap perjanjian yang telah dibuat.

Pemutakhiran dari suatu rencana pajak adalah konsekuensi yang perlu dilakukan sebagaimana dilakukan oleh masyarakat yang dinamis. Dnegan memberikan perhatian terhadap perkembangan yang akan datang maupun situasi yang akan terjadi saat ini, seorang manajer akan mampu mengurangi akibat yang merugikan dari adanya perubahan, dan pada saat bersamaan mampu mengambil kesempatan untuk memperoleh manfaat yang potensial.

\section{KERANGKA KONSEPTUAL}

Kerangka dasar implementasi tax planning PT Graha Power Energy dapat digambarkan sebagai berikut. 


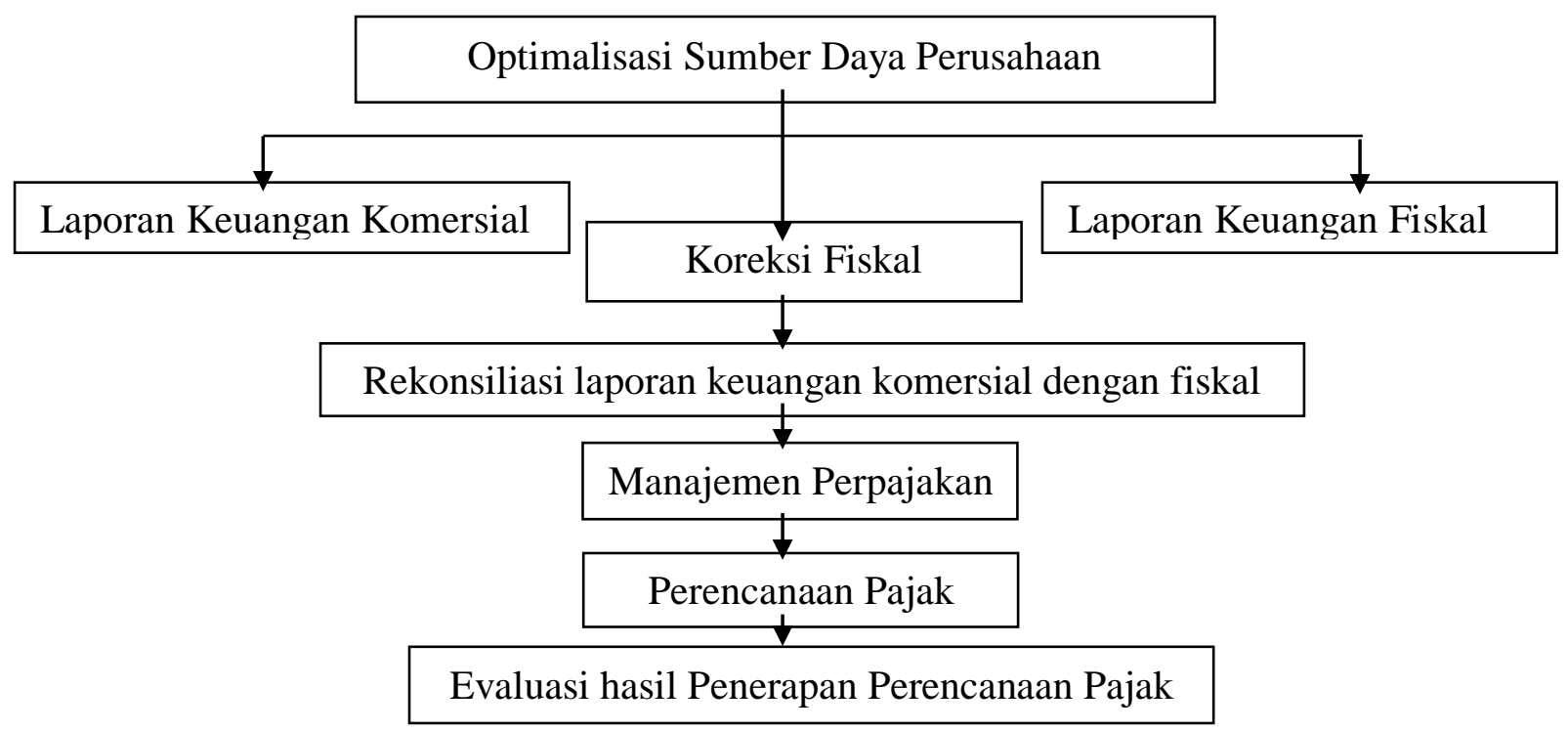

Gambar 1. Kerangka Konseptual

\section{METODE PENELITIAN}

\section{Populasi dan sampel}

Populasi dan sampel dalam penelitian adalah 21 Karyawan Tetap pada PT Graha Power Energy.

\section{Metode Pengumpulan Data}

Teknik pengumpulan data dalam penelitian ini meliputi: 1) Interview (Wawancara); Menurut Sugiyono (2012), Wawancara digunakan sebagai teknik pengumpulan data apabila peneliti ingin melakukan studi pendahuluan untuk menemukan permasalahan yang harus diteliti, dan juga apabila peneliti ingin mengetahui hal-hal dari responden yang lebih mendalam dan jumlah respondennya sedikit/kecil. mengadakan tanya jawab dengan staff accounting dan pajak untuk memperoleh data yang lebih objektif. 2) Observasi; Menurut Sugiyono (2012), observasi sebagai teknik pengumpulan data mempunyai ciri yang spesifik bila dibandingkan dengan teknik yang lain, yaitu wawancara. Kalau wawancara selalu berkomunikasi dengan orang, maka observasi tidak terbatas pada orang, tetapi juga objek-objek alam yang lain. 3) Studi Kepustakaan; mengambil beberapa buku bacaan atau literatur sebagai bahan acuan masalah yang diteliti untuk mendukung data primer yang telah diperoleh dari studi lapangan. Data sekunder ini diperoleh dari buku, artikel, internet, serta dokumendokumen instansi yang berkaitan dengan tema skripsi ini. Data kepustakaan yang diperlukan peneliti dalam penelitian ini adalah ketentuan peraturan perpajakan yang berlaku khususnya yang mengatur tentang Pajak Penghasilan (PPh) Pasal 21. Peneliti juga menggunakan data laporan keuangan perusahaan yang telah diaudit, rekap gaji, dan kompensasi pegawai tetap.

\section{Teknik Analisis Data}

Dalam penelitian ini menggunakan metode deskriptif analisis kuantitatif, yaitu menganalisis, mengumpulkan dan mengevaluasi Perencanaan Pajak (Tax Planning) untuk Penghematan jumlah Pajak Penghasilan pada PT Graha Power Energy. Dengan penelitian ini, menggambarkan bagaimana PT Graha Power Energy melaksanakan perencanaan pajak perusahaannya guna meminimalkan pajak terutang yang harus dibayarkan perusahaan. Penelitian ini juga akan melihat perencanaan pajak dari sisi teoritis dan membandingkan dengan keadaan sebenarnya yang dilaksanakan pada PT Graha power Energy. 


\section{HASIL PENELITIAN DAN PEMBAHASAN}

Pajak mempunyai dampak yang cukup besar terhadap kegiatan perusahaan. Pemilik perusahaan tentunya ingin menikmati hasil usahanya secara maksimal. Oleh karena itu perlu disusun suatu perencanaan pajak yang dikoordinasikan dengan rencana jangka panjang dan rencana pendek perusahaan. Alasan - alasan dilakukannya perencanaan pajak bagi perusahaan: 1) Pajak merupakan pengeluaran bagi manajemen. Oleh karena ituperencanaan pajak yang baik akan mengurangi beban yang harus ditanggung perusahaan. 2) Perencanaan pajak yang baik akan menghemat biaya yang seharusnya dikeluarkan tanpa harus menghemat biaya yang seharusnya dikeluarkan tanpa harus menghadapi tuntutan dari fiskus.

\section{Pembahasan}

Pada bab pembahasan menganalisa manajemen pajak yang dilakukan PT Graha Power Energy dalam mengoptimalkan pajak penghasilannya. Dari pembahasan ini juga akan terlihat apakah manajemen pajak yang telah diterapkan dalam Graha Power Energy sudah berjalan efisien sehingga dapat menimalkan pajak penghasilan terutang.

\section{Kepegawaian Dalam PT Graha Power Energy}

Sampai dengan tahun 2013, Graha Power Energy mempunyai 30 Orang pegawai, dimana 15 orang adalah pegawai tetap dan 15 orang adalah pegawai kontrak. Pegawai kontrak tetap masuk dalam kategori sebagai pegawai tetap. Karena perusahaan sedang mengerjakan sebuah proyek biasanya memakai jasa pegawai tidak tetap yang dibayarkan dengan upah harian atau upah borongan. Berikut penjelasan mengenai jenis kepegawaian dalam PT Graha Power Energy.
1) Pegawai tetap dan pegawai kontrak

Berpedoman kepada undangundang No. 36 Tahun 2008 dan Peraturan Menteri keuangan No. 252/PMK.03/2008, pegawai tetap adalah pegwai yang menerima atau memperoleh penghasialn dalam jumlah tertentu secara teratur, termasuk anggota dewan komisaris dan anggota dewan pengawas yang secara teratur terus menerus ikut mengelola kegitan perusahaan secara langsung, serta pegawai yang bekerja berdasarkan kontrak untuk suatu jangka waktu tertentu sepanjang pegawai yang bersangkutan bekerja penuh (full time) dalam pekerjaan tersebut.

Berdasarkan pengertian diatas maka pegawai kontrak termasuk sebagai pegawai tetap. Pegawai kontrak dipekerjakan oleh perusahaan untuk jangka waktu tertentu saja, masa kontrak pada PT Graha Power Energy adalah selama 2 (dua) tahun. Hubungan kerja dapat dilanjutkan atau tidak tergantung dari hasil evaluasi perusahaan terhadap pegawai kontrak tersebut, dan disesuaikan dengan kebutuhan perusahaan.

Hubungan kerja antara perusahaan dan karyawan dituangkan dalam Perjanjian Kerja Untuk Waktu Tertentu (PKWT). Apabila salah satu pihak mengakhiri hubungan kerja sebelum berakhirnya jangka waktu yang ditetapkan dalam perjanjian kerja waktu tertentu, maka pihak yang mengakhiri hubungan kerja diwajibkan membayarganti rugi kepada pihak lainnya sebesar gaji karyawan sampai batas waktu berakhirnya jangka waktu perjanjian kerja (pinalti). Sedangkan untuk karyawan tetap tidak ada batasan mengenai jangka waktu.

Hubungan kerja antara perusahaan dan karyawan tetap dituangkan dalam Perjanjian Kerja Untuk Waktu Tidak Tertentu (PKWTT). Perusahaan mensyaratkan masa percobaan selama 3 (tiga) bulan dan akan dihitung sebagai 
masa kerja. Mengenai hak dan kewajiban, gaji , fasilitas, kesejahteraan, dll, pegawai kontrak memiliki hak yang sama dengan pegawai tetap.

2) Pegawai Tidak Tetap

Pegawai tidak tetap/tenaga kerja lepas adalah pegawai yang hanya menerima penghasilan apabila pegawai yang hanya menerima penghasilan apabila pegawai yang bersangkutan bekerja, berdasarkan jumlah hari bekerja, jumlah unit hasil pekerjaan yang dihasilkan atau penyelesaian sutau jenis pekerjaan yang diminta ole pemberi kerja. Penghasilan pegawai tidak tetap atau tenaga kerja lepas, berupa upah harian, upah mingguan, upah satuan, upah borongan atau upah yang dibayarkan secara bulanan. a. Upah harian adalah harian adalah upah atau imbalan yang diterima atau diperoleh pegawai yang terutang atau dibayarkan secara harian. b. Upah mingguan adalah upah atau imbalan yang diterima atau diperoleh pegawai yang terutang atau dibayarkan secara mingguan. c. Upah satuan adalah upah atau imbalan yang diterima atau diperoleh pegawai yang terutang atau dibayarkan berdasarkan jumlah unit hasil pekerjaan yang dihasilkan. d. Upah borongan adalah upah atau imbalan yang diterima atau diperoleh pegawai yang terutang atau dibayarkan berdasarkan penyelesaian suatu jeni pekerjaan tertentu.

Selama ini perusahaan membayar tenaga pegawai tidak tetap dengan upah borongan, karena dianggap lebih praktis dan lebih efisien. Proyek-proyek yang biasa diperoleh PT Graha Power Energy juga memungkinkan untuk sistem penggajian dengan upah borongan. Berikut contoh perhitungan Upah Borongan.

\section{Beban Gaji Pegawai Pada PT Graha Power Energy}

Beban Gaji Pegawai PT Graha Power Energy merupakan akun yang mencatat pengeluaran untuk kepentingan penggajian pegawai. Beban Gaji terdiri dari : gaji pokok, uang lembur, dan THR. Berdasarkan undang-undang PPh 36 tahun 2008 pasal 4 ayat 1 dikatakan bahwa " Yang menjadi objek pajak adalah penghasilan, yaitu setiap tambahan kemampuan ekonomis yang diterima atau diperoleh Wajib Pajak, baik yang berasal dari Indonesia maupun dari luar Indonesia, yang dapat dipakai untuk konsumsi atau untuk menambah kekayaan Wajib Pajak yang bersangkutan, dengan nama dan dalam bentuk apapun". Beban Gaji Pegawai Pada PT Graha Power Energy yang terdiri dari gaji pokok, uang lembur, dan THR ini merupaka tambahan ekonimis yang diterima karyawan dan dapat dipakai untuk konsumsi atau menambah kekayaan wajib pajak sehingga gaji pokok, uang lembur dan tunjangan hari raya yang diberikan PT Graha Power Energy kepada karyawannya $\mathrm{PPh}$ pasal 21 nya ditanggung oleh pegawai dan langsung dipotong dari penghasilan para pegawai. Berikut komponen beban gaji pegawai tetap di PT Graha Power Energy sebagai berikut: 1) Gaji Pokok; Adalah sejumlah uang yang diterima setiap bulannya oleh pegawai sesuai dengan strata jabatan dan jabatnnya serta tidak terkait dengan prestasi kerja yang bersangkutan. Gaji pokok dianggap sebagai kompensasi terhadap beban kerja dan tanggung jawab pegawai pada jabatan yang diembannya. 2) Uang Lembur; Diberikan kepada pegawai, apabila pegawai bekerja diatas jam kerja normal (diatas jam lima sore), uang lembur ini akan langsung ditambahkan pada gaji pegawai yang bersangkutan tiap bulannya (bila ada lembur). 3) Tunjangan Hari Raya; Tunjangan ini diberikan PT Graha Power Energy sesuai dengan kepercayaan yang dianut pegawai. Bagi pegawai yang beragama muslim akan menerima THR pada saat lebaran, sedangkan untuk pegawai yang beragama 
kristen akan menerima THR pada saat natal, begitupun dengan agama yang lain. THR diberikan berdasarkan masa kerja pegawai. Untuk pegawai yang bekerja lebih dari 1 tahun, maka THR yang diterima 1 kali dari gaji pokok, sedangkan pegawai yang masa kerjanya kurang dari 1 tahun, maka hanya menerima THR secara prorata sesuai jumlah masa kerja.

\section{Manajemen Pajak PPH Pasal 21}

Sejak PT Graha Power Energy berdiri tahun 2005, baru 4 tahun terakhir PT Graha Power Energy melakukan manajemen pajak untuk pajak penghasilan 21. Metode perhitungan pajak yang digunakan perusahaan adalah Gross basis method dimana dalam metode perhitungan pajak ini jumlah $\mathrm{PPh}$ Pasal 21 yang terutang ditanggung oleh karyawan sendiri. Penghasilan karyawan akan berkurang karena pemotongan tersebut, sedangkan bagi perusahaan seluruh gaji kotor karyawan dapat dikurangkan sebagai beban perusahaan. Salah satu tujuan penggajian adalah untuk memuaskan dan memotivasi karyawan.

Benefit in Cash

Merupakan pemberian perusahaan kepada karyawan dalam bentuk cash. Pemberian dalam bentuk ini merupakan pengurang penghasilan bruto bagi perusahaan dan objek PPh 21 bagi karyawan. Dasar hukumnya pasal 6 (1) huruf a.2 UU No. 36 tahun 2008. Perusahaan mempertimbangkan kira-kira benefit in cash apa yang diperlukan oleh karyawan untuk meningkatkan kesejahteraannya. Tunjangan kas akhirnya perusahaan lakukan berkaitan dengan perencanaan pajak adalah: a. Tunjangan Kesehatan; Kesehatan adalah hal yang utama bagi semua orang. Kesehatan juga menjadi salah satu hal yang dapat mempengaruhi kinerja pegawai yang berpengaruh pada efisiensi kegiatan perusahaan. Perusahaan memberikan dua jenis asuransi kesehatan, yang pertama adalah asuransi kesehatan tahunan dengan mengunakan provider asuransi kesehatan. Namun asuransi kesehatan tahunan tersebut hanya bisa mengcover asuransi untuk rawat inap saja dan tidak termasuk biaya melahirkan dan rawat jalan. Oleh karena itu, untuk rawat jalan dan juga biaya melahirkan, perusahaan mempunyai kebijakan memberikan tunjangan kesehatan berupa uang tunai. Tak hanya menambah penghasilan yang akan diterima pegawai, bagi perusahaan tunjangan kesehatan juga dapat dikurangkan sebagai biaya dalam menghitung Penghasilan Kena Pajak Akhir (Pasal 6 ayat 1 UU No. 36 Tahun 2008).

PT Graha Power Energy memberikan tunjangan kesehatan untuk karyawannya yang berjumlah 30 orang. Besarnya tunjangan kesehatan yang dibebankan sebagai biaya yang harus dikeluarkan oleh PT Graha Power Energy dalam satu tahun adalah:

\section{Rp. 75,000.00 $\times 30$ Orang $\times 12$ bulan $=$ Rp. 27,000,000.00}

b. Tunjangan Makan; PT Graha Power Energy memilih memberikan tunjangan makan secara tunai. Dengan alasan tunjangan makan secara tunai dapat dibebankan dalam perhitungan pajak penghasilan perusahaan. Namun dari sisi pegawai akan ada penambahan jumlah PPh Pasal 21 karena tunjangan makan secara tunai merupakan penambah penghasilan bagi karyawan. Alasan mengapa perusahaan tidak memberikan tunjangan makan dengan pemberian makan karena dalam peraturan Menteri Keuangan No. 83/PMK.03/2009 tentang "Penyediaan makanan dan minuman bagi seluruh pegawai serta penggantian atau imbalan dalam bentuk natura dan kenikmatan di daerah tertentu dan yang berkaitan dengan pelaksanaan pekerjaan yang dapat dikurangkan dari penghasilan bruto pemberi kerja", pemberian makanan dan minuman yang disediakan 
oleh pemberi kerja bagi seluruh pegawai ditempat kerja memang dapat dikurangkan dari penghasilan bruto pemberi kerja tetapi bukan merupakan penghasilan bagi pegawai yang menerimanya. Sehingga perusahaan tetap memberikan tunjangan makan dalam bentuk tunai, jumlahnya dalam 1 tahun sebesar:

Rp. 15,000.00 x 30 Orang $x 26$ hari kerja $x 12$ bulan $=$ Rp. $140,400,000.00$

c. Tunjangan Transport; Tunjangan Transport secara tunai dipandang perusahaan lebih efektif dibanding dengan pemberian mobil atau motor kantor untuk digunakan karyawan, ataupun dengan memberikan fasilitas jemputan untuk karyawan. Karena ketiga cara tersebut akan mengeluarkan biaya yang lebih banyak dibanding pemberian tunjangan transport secara tunai setiap bulan. Tak hanya dibanding lebih praktis, pemberian tunjangan transport akan menambah penghasilan yang akan diterima karyawan, tetapi bagi perusahaan tunjangan transport juga dapat dikurangkan sbeagai biaya adlam menghitung penghasilan kena pajak akhir. Besarnya tunjangan transport dalam setahun adalah:

Rp. 15,000.00 x 30 Orang x 26 Hari Kerja $x 12$ Bulan $=$ Rp. 140,400,000.00

d. Natura; Merupakan pemberian perusahaan kepada karyawan dalam bentuk non tunai berupa kenikmatan. Pemberian dalam bentuk natura bagi perusahaan tidak dapat dijadikan sebagai pengurang penghasilan bruto dan bagi karyawan bukan merupakan objek $\mathrm{PPh}$ 21. Oleh karena itu, perusahaan hanya memberikan pemberian tunjangan dalam bentuk biaya telepon. Biaya telepon belum termasuk biaya pulsa handphone yang digunakan oleh bagian marketing sehingga menurut KEP-220/PJ/2002 mulai 18 April 2002 hingga sekarang voucher atau pulsa handphone dapat dibebankan sebagai biaya oleh perusahaan (deductible) tetapi hanya 50\% saja.

Rp. 58.121.704 x 50\% = Rp. 29.060.852

Perbandingan perhitungan PPh 21 sebelum perencanaan pajak dan setelah perencanaan pajak

Perencanaan pajak yang dilakukan oleh perusahaan dalam bentuk tunjangantunjangan, baik dalam bentuk tunai atau natura tentu sangat menguntungkan dari sisi pegawai. Tunjangan dalam bentuk tunai tentunya membuat pajak penghasilan 21 karyawan meningkat, tetapi di sisi lain juga terlihat bahwa jumlah penghasilan yang diterima pegawai meningkat akibat tunjangan dalam bentuk tunai yang merupakan cara perencanaan pajak yang perusahaan lakukan. Berikut akan diperlihatkan perbedaan Pajak Penghasilan 21 pegawai sebelum adanya perencanaan pajak berupa tunjangan tunai dan setelah perencanaan pajak dalam bentuk tunjangan tunai.

\section{Pajak Penghasilan Badan yang dibayarkan sebelum penerapan perencanaan pajak}

Untuk memperjelas perbedaan dengan sebelum dan sesudah adanya penerapan perencanaan pajak dalam usaha meminimalkan pengeluaran pajak perusahaan maka dibawah ini terdapat laporan laba rugi sebelum menerapkan perencanaan pajak. 
Tabel 3. PT Graha Power Energy Laporan Laba Rugi Per 31 Desember 2013

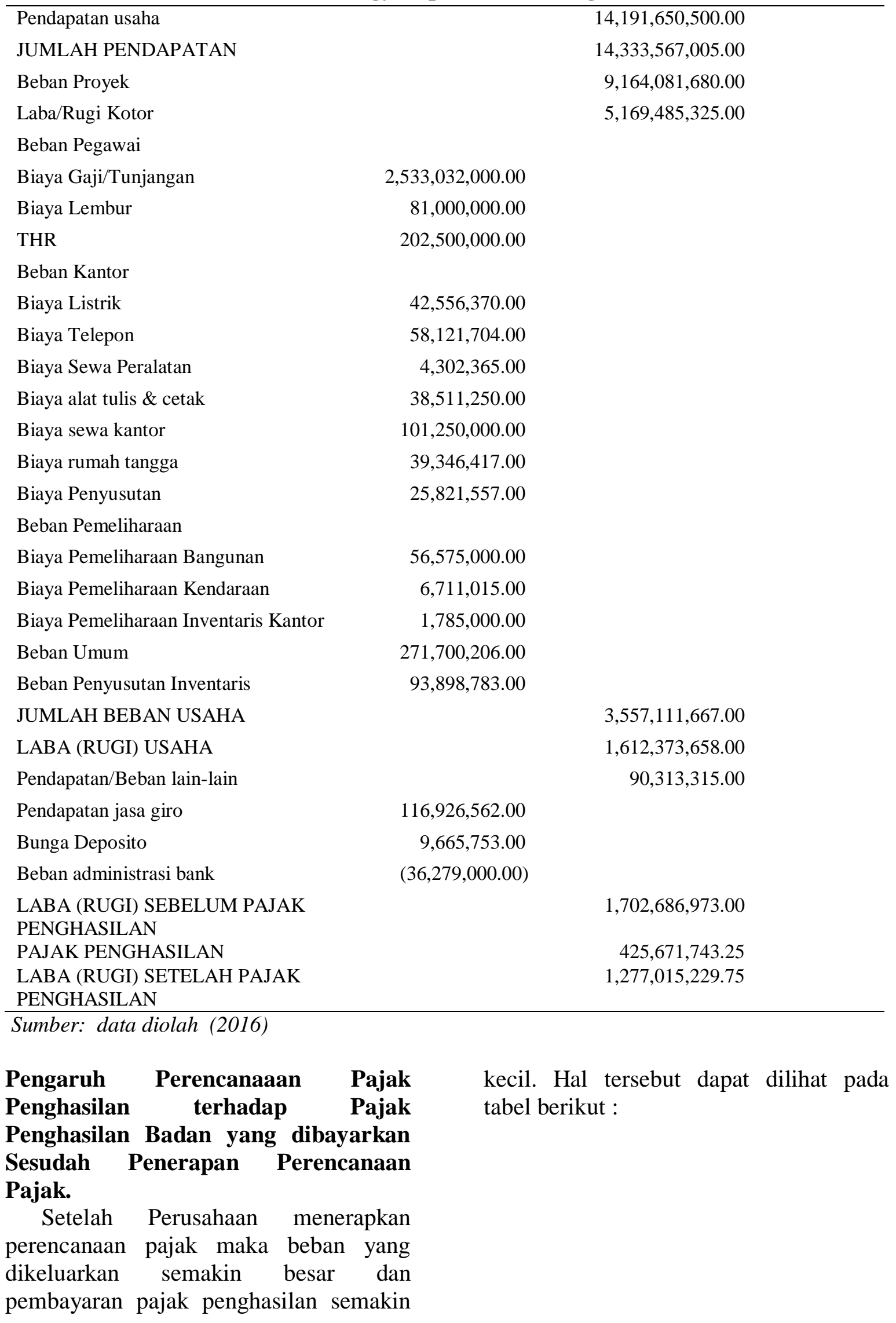


Tabel 4. PT Graha Power Energy Laporan Laba Rugi Setelah Penerapan Perencanaan Pajak Per 31 Desember 2013

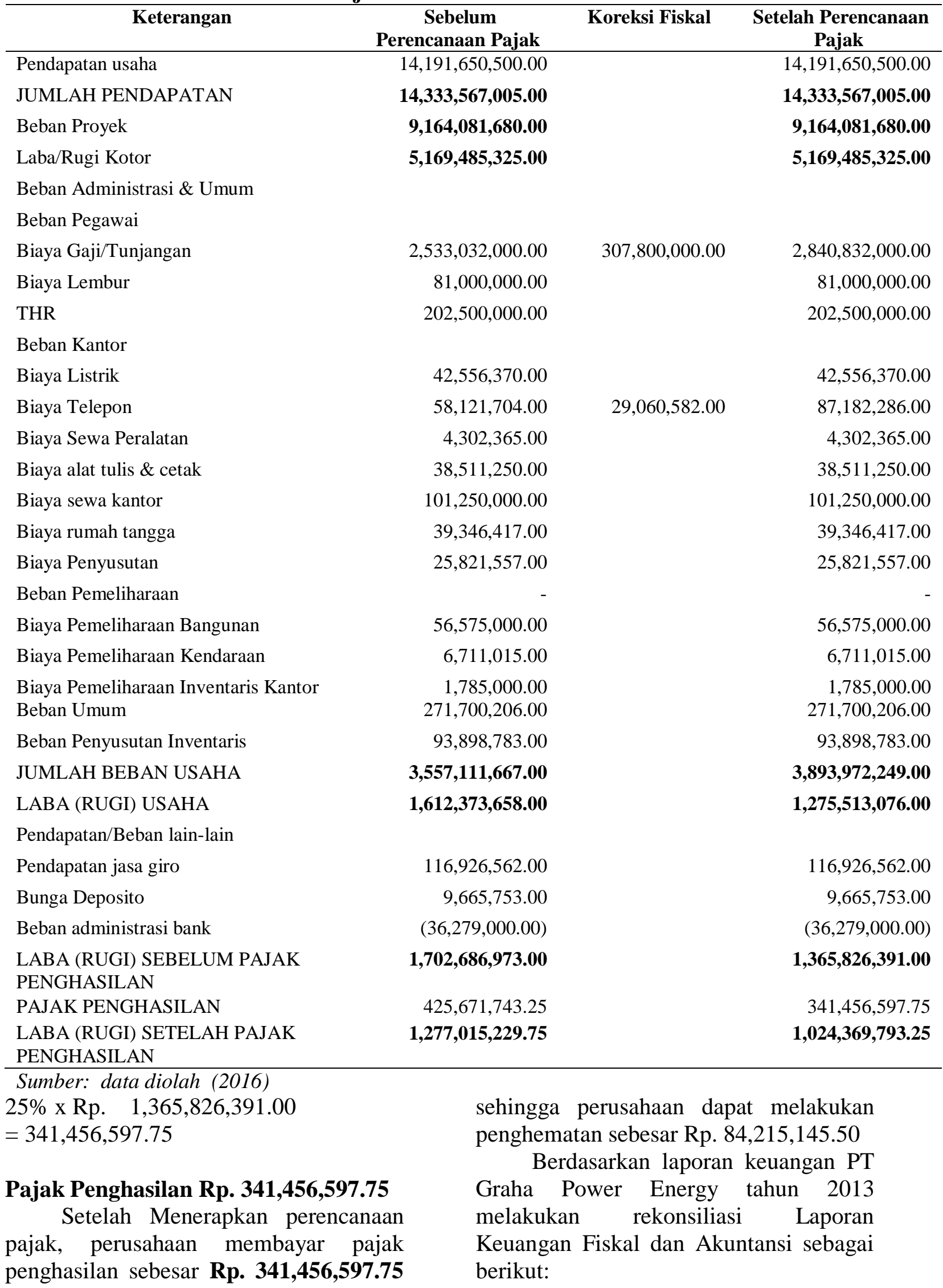


1. Tunjangan kesehatan, tunjangan makan dan transportasi yang diperoleh oleh karyawan, diakui oleh perpajakan sebagai objek pajak. Oleh karena itu perusahaan melakukan perencanaan pajak dengan menggabungkan tunjangan kesehatan, tunjangan makan dan tunjangan transport ke dalam biaya gaji/tunjangan, sehingga diperoleh hasil perhitungan:

Rp. $\quad 27,000,000.00+$ Rp. $140,400,000.00$ + Ro. $140,400,000.00$ $=$ Rp. $307,800,000$
2. Biaya telepon dikenai koreksi fiskal karena hanya $50 \%$ dari voucher telepon yang bisa diakui sebagai pengurang pajak yaitu sebesar Rp. 58.121 .704 x $50 \%=$ Rp. 29.060 .852

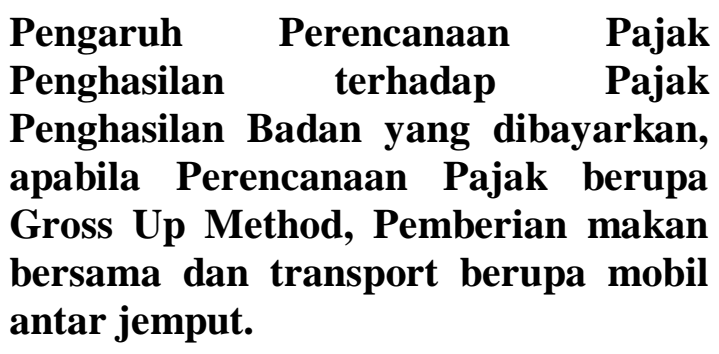

Pengaruh Perencanaan Pajak Penghasilan terhadap Pajak Penghasilan Badan yang dibayarkan, apabila Perencanaan Pajak berupa Gross Up Method, Pemberian makan bersama dan transport berupa mobil put.

Tabel 5. PT Graha Power Energy Laporan Laba Rugi Perencanaan Pajak Alternatif Per 31 Desember 2013

\begin{tabular}{|c|c|c|c|}
\hline Keterangan & $\begin{array}{c}\text { Sebelum Perencanaan } \\
\text { Pajak }\end{array}$ & Koreksi Fiskal & $\begin{array}{c}\text { Setelah Perencanaan } \\
\text { Pajak }\end{array}$ \\
\hline Pendapatan usaha & $14,191,650,500.00$ & & $14,191,650,500.00$ \\
\hline JUMLAH PENDAPATAN & $14,333,567,005.00$ & & $14,333,567,005.00$ \\
\hline Beban Proyek & $9,164,081,680.00$ & & $9,164,081,680.00$ \\
\hline Laba/Rugi Kotor & $5,169,485,325.00$ & & $5,169,485,325.00$ \\
\hline \multicolumn{4}{|l|}{ Beban Administrasi \& Umum } \\
\hline \multicolumn{4}{|l|}{ Beban Pegawai } \\
\hline Biaya Gaji/Tunjangan & $2,533,032,000.00$ & & $2,533,032,000.00$ \\
\hline Biaya Lembur & $81,000,000.00$ & & $81,000,000.00$ \\
\hline THR & $202,500,000.00$ & & $202,500,000.00$ \\
\hline Biaya Makan Bersama & & & $117,000,000.00$ \\
\hline Biaya Transportasi Pegawai & & & $117,000,000.00$ \\
\hline Beban Pajak & & & $81,939,258.90$ \\
\hline \multicolumn{4}{|l|}{ Beban Kantor } \\
\hline Biaya Listrik & $42,556,370.00$ & & $42,556,370.00$ \\
\hline Biaya Telepon & $58,121,704.00$ & $29,060,582.00$ & $87,182,286.00$ \\
\hline Biaya Sewa Peralatan & $4,302,365.00$ & & $4,302,365.00$ \\
\hline Biaya alat tulis \& cetak & $38,511,250.00$ & & $38,511,250.00$ \\
\hline Biaya sewa kantor & $101,250,000.00$ & & $101,250,000.00$ \\
\hline Biaya rumah tangga & $39,346,417.00$ & & $39,346,417.00$ \\
\hline Biaya Penyusutan & $25,821,557.00$ & & $25,821,557.00$ \\
\hline Beban Pemeliharaan & - & & - \\
\hline Biaya Pemeliharaan Bangunan & $56,575,000.00$ & & $56,575,000.00$ \\
\hline Biaya Pemeliharaan Kendaraan & $6,711,015.00$ & & $6,711,015.00$ \\
\hline Biaya Pemeliharaan Inventaris Kantor & $1,785,000.00$ & & $1,785,000.00$ \\
\hline Beban Umum & $271,700,206.00$ & & $271,700,206.00$ \\
\hline Beban Penyusutan Inventaris & $93,898,783.00$ & & $93,898,783.00$ \\
\hline
\end{tabular}


JUMLAH BEBAN USAHA

LABA (RUGI) USAHA

Pendapatan/Beban lain-lain

Pendapatan jasa giro

Bunga Deposito

Beban administrasi bank

LABA (RUGI) SEBELUM PAJAK

PENGHASILAN

PAJAK PENGHASILAN

LABA (RUGI) SETELAH PAJAK

PENGHASILAN

Sumber: data diolah (2016)

Apabila PT Graha Power Energy menerapkan kebijakan perencanaan pajak dengan membebankan pajak dengan metode gross up dan memberikan makan bersama pada karyawan dan menyediakan transportasi dalam bentuk mobil jemputan, maka PPh Badan yang harus dibayarkan adalah:

$25 \% \times \operatorname{Rp} 1,357,687,132.10=$ Rp 339,421,783.02

\section{Total Pajak Penghasilan Rp.} 339,421,783.02

\section{Interpretasi Penelitian}

Dari hasil analisis diatas, perencanaan pajak dalam bentuk tunjangan tunai yang dilakukan PT Graha Power Energy mengakibatkan pajak

\begin{tabular}{lccc} 
Power Energy & mengakibatkan & pajak & \\
\hline \multicolumn{1}{c}{ Keterangan } & $\begin{array}{c}\text { Sebelum Perencanaan } \\
\text { Pajak }\end{array}$ & $\begin{array}{c}\text { Setelah Perencanaan } \\
\text { Pajak }\end{array}$ & $\begin{array}{c}\text { Perencanaan Pajak } \\
\text { Alternatif }\end{array}$ \\
\hline Laba Sebelum Pajak & $1,702,686,973.00$ & $1,365,826,391.00$ & $1,357,687,132.10$ \\
Tarif PPh Badan 25\% & $425,671,743.25$ & $341,456,597.75$ & $339,421,783.02$ \\
\hline
\end{tabular}

$116,926,562.00$

$116,926,562.00$

$9,665,753.00$

$9,665,753.00$

$(36,279,000.00)$

$(36,279,000.00)$

$1,702,686,973.00$

$425,671,743.25$

$1,277,015,229.75$
$1,357,687,132.10$

$339,421,783.02$ $\mathbf{1 , 0 1 8 , 2 6 5 , 3 4 9 . 0 7}$ penghasilan 21 untuk pegawai naik, dan membuat pengeluaran lebih untuk membayar 3 tunjangan tunai tersebut. Tetapi pada keseluruhannya memberikan efek pada penurunan $\mathrm{PPh}$ terutang badan. Dengan adanya penerapan perencanaan pajak menyebabkan beban pajak semakin kecil maka $\mathrm{PPh}$ yang terutang semakin kecil juga. Sedangkan perencanaan pajak alternatif yang dibuat oleh, yaitu pemberian makan bersama di kantor dan penyediaan mobil untuk transportasi antar - jemput karyawan ternyata memberikan penghematan pajak yang paling baik dibandingkan tanpa perencanaan pajak dan dengan perencanaan pajak dalam bentuk tunjangan tunai, hasilnya akan dijelaskan pada tabel berikut:

Sumber: data diolah (2016)

\section{KESIMPULAN DAN SARAN}

Berdasarkan hasil penelitian pada PT Graha Power Energy maka dapat ditarik beberapa kesimpulan sebagai berikut: 1) Perencanaan pajak yang dilakukan perusahaan terbagi menjadi 2 cara, yaitu: a. Pemberian Tunjangan Tunai; Tunjangan kesehatan, tunjangan makan, dan tunjangan transportasi yang diberikan akan menambah penghasilan karyawan, tunjangan tersebut boleh dibebankan oleh perusahaan. b. Pemberian Natura; Pemberian natura atau kenikmatan yang diberikan perusahaan adalah dalam bentuk pemberian voucher pulsa telepon yang digunakan untuk kebutuhan karyawan. Natura dalam bentuk voucher pulsa telepon dapat dibebankan sebesar 50\%. 2) Selisih yang terjadi setelah 
menerapkan perencanaan pajak merupakan penghematan pajak yang dapat diperoleh oleh perusahaan. Dimana sebelum penerapan perencanaan pajak, pajak penghasilan yang harus dibayar perusahaan adalah Rp. 425,671,743.25 dan setelah melakukan perencanaan pajak menjadi Rp. 341,456,597.75 Sehingga diperoleh penghematan pajak sebesar Rp. $\mathbf{8 4 , 2 1 5 , 1 4 5 . 5 0}$ selisih tersebut dapat digunakan perusahaan untuk hal yang lebih berguna dan bermanfaat. 3) Semua perencanaan pajak yang diterapkan oleh PT Graha Power Energy sudah sesuai dengan peraturan yang berlaku.

Dari kesimpulan diatas, dapat memberikan beberapa saran untuk PT Graha Power Energy agar dapat lebih memaksimalkan perencanaan pajak, yaitu: a. Dengan adanya perencanaan pajak pada PT Graha Power Energy yang terdapat penghematan pajak sebesar Rp. 84,215,145.50, diharapkan PT Graha Power Energy melakukan pembayaran pajak tepat waktu sesuai dengan ketentuan yang berlaku. Pada pasal 3 ayat (3) Undang-undang 6 tahun 1983 sebagaimana telah diubah terakhir dengan undang-undang No. 28 Tahun 2007 (UU KUP), disebutkan bahwa batas pembayaran pajak terutang adalah empat bulan setelah batas akhir tahun buku perusahaan (akhir april). Dengan PT Graha Power Energy membayar pajak tepat waktu, akan terlihat bahwa perencanaan pajak tidak hanya dapat menghemat pajak, namun juga membuat si wajib pajak membayar pajak tepat waktu, sehingga terbebas dari sanksi administrasi. b. Sebaiknya perusahaan mencari strategi penerapan perencanaan pajak lain yang sesuai dengan peraturan perpajakan yang berlaku sehingga penerapan perencanaan pajak PT Graha Power Energy dapat lebih maksimal.Seperti untuk tahun mendatang PT Graha Power Energy dapat meulai perencanaan dengan tidak hanya memberikan benefit in cash dan natura saja untuk dapat meminimalkan pajak terutang yang harus dibayar perusahaan, tetapi juga dapat melakukan perencanaan pajak dengan melakukan metode gross up yaitu memberikan tunjangan pajak pada karyawan seperti yang dilakukan banyak perusahaan. Perencanaan pajak dalam bentuk makan bersama sepertinya akan lebih dapat menghemat total pembayaran pajak daripada pemberian tunjangan makan yang ditambahkan ke penghasilan. Dengan makan bersama, juga dapat menambah keakraban diantara pegawai. Seperti telah di contohkan dengan memberikan tunjangan pajak dan makan bersama penghematan yang dapat dilakukan jauh lebih besar daripada perencanaan pajak dengan tunjangan tunai yaitu sebesar Rp. 86,249,960.23.

\section{Keterbatasan Penelitian}

a. Dalam melakukan penelitian ini, keterbatasan-keterbatasan yang dialami diantanya : Keterbatasan waktu dalam melakukan penelitian, dimana penelitian ini dimulai pada bulan November 2014 sampai dengan bulan April 2015 pada tahap penyusunan variabel, pengumpulan bahan teori untuk tinjauan pustaka, pengumpulan data dari perusahaan, dan pengolahan data dan analisa data.

b. Tingkat partisipasi perusahaan yang masing kurang responsif.

\section{DAFTAR PUSTAKA}

Anonim, 2008, Undang-undang Nomor 36 Tahun 2008 tentang perubahan Keempat atas undang-undang Nomor 7 Tahun 1983 tentang Pajak Penghasilan.

Anonim, 2009, Undang-Undang Nomor 16 tahun 2009 tentang perubahan keempat atas Undang-Undang Nomor 6 tahun 1983 tentang Ketentuan Umum dan Tata Cara Perpajakan Pada Pasal 1 ayat 1. 
Erly, Suandy, 2012, Perpajakan, Edisi Keenam, Jakarta: Salemba Empat

Imam Ali Wafa, 2013, Penerapan Perencanaan Pajak Penghasilan Pasal 21 Sebagai Strategi Penghematan Pembayaran Pajak Perusahaan (Studi Kasus pada PDAM Kabupaten Banyuwangi, Skripsi, Universitas Jember

Mardiasmo, 2013, Perpajakan, Edisi revisi, Yogyakarta: Andi Publisher.

Muyassaroh, Etty, 2012, Perpajakan Brevet $A$ dan $B$, Edisi Cetakan I, Yogyakarta: Pustaka Yustisia.

Nurjannah, 2013, Implementasi Perencanaan Pajak (Tax Planning) PPh21 Untuk penghematan Jumlah Pajak Penghasilan Pada PT Semen Bosowa Maros, Skripsi, Universitas Hasanuddin.
Resmi, Siti, 2014, Perpajakan Teori dan Kasus, Edisi 8, Buku 1, Jakarta: Salemba Empat.

Sari, Diana, 2013, Konsep Dasar Perpajakan, Bandung: Refika Aditama.

Sugiyono, 2012, Memahami Penelitian Kualitatif, Bandung: Alfabeta.

Thomas, Sumarsan, 2013, Perpajakan Indonesia, Edisi Ketiga, Jakarta: Indeks.

Waluyo, 2013, Perpajakan Indonesia, Buku 1 Edisi 11, Jakarta: Salemba Empat.

www.ortax.org, diakses 10 Agustus 2016

Yaumil Furqa Nianzar, 2014, Implementasi Tax Planning PPh21 Dalam Upaya Meningkatkan Efisiensi Perusahaan Pada PT Pelni Cabang Parepare, Skripsi, Universitas Hasanuddin. 